\title{
Litvinov and Kamenev-Ambassadors Extraordinary: The Problem of Soviet Representation Abroad
}

In November 1917, the Bolshevik Party came to power in Russia with a foreign policy based on "proletarian internationalism" and the aim of spreading the socialist revolution to all parts of Europe. Developed by V. I. Lenin and Leon Trotsky this policy sought to take advantage of the disruption of European society caused by World War I to transform that conflict of state against state into a vast international civil war of class against class. Believing that the peoples of Europe were weary of war and ripe for revolution the Bolsheviks called for the negotiation of a "just and democratic peace" based on the principles of no annexations, no indemnifications and the liberation of all colonial, dependent and oppressed nations. The Bolsheviks hoped that bourgeois governments would be unable to accept these principles and that their failure to do so would generate sufficient popular unrest to ignite revolution everywhere in Europe. ${ }^{1}$

Success in this venture required the Bolsheviks to obtain the largest possible audience for their views. Trotsky, who had been named foreign commissar in the new Soviet government, sought to obtain this audience through a number of demonstrative gestures designed to attract the attention of the war weary peoples of Europe. Not only did he publish the "secret treaties" binding Russia to the Entente, but he also renounced all Russian claims contained in them and called upon the other belligerent powers to renounce their claims as well. More importantly, when the German government agreed to negotiate with the Bolsheviks and a peace conference assembled at BrestLitovsk, Trotsky successfully insisted that its deliberations be made public. The ensuing exercise in "open diplomacy," however, failed to provide the

1. The literature on proletarian internationalism during World War I is quite extensive. The two classics are Merle Fainsod, International Socialism and the World War (Cambridge, Mass., 1935), and Olga Gankin and H. H. Fisher, eds., The Bolsheviks and the World War: The Origin of the Third International (Stanford, 1940). In recent years much new work has been added. See especially N. E. Korolev, Lenin i mezhdunarodnoe rabochee dvizhenie, 1914-1918 (Moscow, 1968); Horst Lademacher, Die Zimmerwalder Bewegung, 2 vols. (The Hague, 1967); and Ia. G. Temkin, Lenin i mezhdunarodnaia sotsial-demokratiia, 1914-1917 (Moscow, 1968). 
Bolsheviks with the continental stage they needed for the dissemination of their propaganda. Confined within the citadel at Brest-Litovsk, the Bolsheviks were separated from their sympathizers throughout Europe and could only talk with the dour representatives of the Central Powers. Although Trotsky himself travelled to Brest-Litovsk to act as "chief prosecutor" of the socialeconomic system which had plunged Europe into war, the foreign commissar knew he was talking to only half a continent. The Allied Powers simply ignored the Soviet regime and silently refused to participate in the peace talks. ${ }^{2}$ At first this did not appear too serious, but, as time passed and revolution failed to materialize in the West, Trotsky became increasingly apprehensive about his failure to draw the Allies into the negotiations. This failure not only provided the Allied governments with a certain degree of protection against the revolutionary strategy of the Bolsheviks, but weakened the Soviet position in general, leaving Trotsky to face the Germans alone at Brest-Litovsk.

How then was Trotsky to break the "conspiracy of silence" with which the Allies had surrounded the Russian Revolution and bring the Bolshevik peace proposals to the attention of the peoples of Western Europe? Having launched his "peace offensive" with a series of demonstrative gestures to attract attention to the revolutionary policy of the Soviet government he continued his attack in the same manner. The Allies had to be shown that they could not ignore the Soviet government, and to teach them this lesson Trotsky sought to demonstrate that the Bolsheviks exercised effective power in Russia. Step by step he taught them this lesson, first by prohibiting the departure of Allied citizens from Russia and then by threatening to sever the communication of Allied governments with their embassies in Petrograd. As a result, he succeeded in forcing the Western powers to enter into a series of unofficial negotiations with the Soviet government which led first to the release of two Russian Social-Democrats imprisoned in Great Britain ${ }^{3}$ and then to Western acknowledgment that Soviet Russia was entitled in principle to reciprocity in questions of diplomatic privilege. If the Allies could use diplomatic couriers and code in communicating with their representatives in Russia then the Soviet government enjoyed the same privileges. ${ }^{4}$

This set the stage for the appointment of Soviet representatives in West-

2. Richard H. Ullman, Intervention and the War (Princeton, 1961); George F. Kennan, Russia Leaves the War (Princeton, 1956); John Bradley, Allied Intervention in Russia, 1917-1920 (London, 1968).

3. Richard K. Debo, "The Making of a Bolshevik: Georgii Chicherin in England, 1914-1918," Slavic Review, 25, no. 4 (December 1966).

4. Great Britain, Public Record Office, London. Foreign Office Papers,. Record Group 371, Volume 3020, Document 237030. Foreign Office papers will henceforth be cited as PRO F.O. 371 followed by the volume and document numbers. See also PRO F.O. $371 / 3019 / 229362 ; 371 / 3020 / 233970,242028$. 
ern Europe-necessary not only to spread revolutionary propaganda, but also to improve the general political position of the Soviet government. As matters stood at the end of 1917, Trotsky was at a decided disadvantage in conducting relations with the Allied Powers. The concessions which he had just wrung from them established a form of unofficial contact with the Western capitals, but all business was transacted in Petrograd through agents who possessed little political influence. Whereas the Western powers continued to operate numerous agencies in Russia and had access to all information available in the chaotic conditions which prevailed at the time, the Soviet government had no representatives in Western Europe, was cut off from its political sympathizers there and disposed of only very limited information published by the official news agencies of the Allied governments. Thus, the Allies could act freely in Russia to advance what they considered their best interests, maintaining contact with both the Bolsheviks and their adversaries, while the Soviet government was powerless even to influence public opinion in Western Europe. This was a politically ruinous arrangement and not one which Trotsky was prepared to tolerate for long.

Nor was tolerance necessary, for if the Allies enjoyed an advantage in Russia the Soviet government had it within its power to reduce that advantage. The foreign commissar had already discovered that the Allied governments were susceptible to pressure, and he did not hesitate to apply further pressure to secure what he wanted. Above all else he wanted Soviet representation abroad, reliable Soviet agents in Western Europe who, while representing Bolshevik views to the Allied governments, could also, with the protection of diplomatic immunity, influence public opinion in Britain and France. Having already won the right to send diplomatic couriers to Western Europe Trotsky turned to this new objective.

Strategic, tactical and practical reasons led him to choose Great Britain as the first target in his campaign to secure international representation. Strategically, Britain, with its massive industrial proletariat and tradition of political freedom, appeared vulnerable to Bolshevik agitation. With the exception of revolution in Germany, a Bolshevik triumph in Britain would do more than anything else to assure the success of the world workers revolution. Tactically, the Bolsheviks hoped to benefit from the flexibility of the British government. In December, London had shown a greater tendency to make concessions than any other Allied capital, and Trotsky had no reason to believe that the British had grown more rigid in their policy. To be sure, these concessions had been made only to protect British interests and had been yielded with ill-concealed bad grace, but they had been made nonetheless and had forced similar concessions from the other Allies as well. The Bolsheviks could reasonably assume that if Whitehall agreed to receive a Soviet 
ambassador the other Allies would follow suit, if for no other reason than to protect their interests in Russia against British encroachment. Finally, in a practical sense, Britain was chosen because, unlike other Allied countries, it sheltered a sizeable community of Russian political émigrés, among whom were several Bolsheviks who could adequately assume the duties of ambassador. On December 30, 1917, Trotsky appointed Maxim Litvinov as Soviet chargé d'affaires in London.

What was the reaction of the British government to this appointment? Initially, it was one of astonishment, with the Foreign Office eager to discover the identity of Litvinov. From its own sources and those of the Home Office it was learned that Litvinov was a Russian Social Democrat known to the police by a variety of names. He had lived in London since 1909 and made his living as a language teacher employed by civil servants and industrial agents wishing to learn Russian. His most notable clients were Messrs. Vickers, the munition manufacturers, and Reginald Leeper, a specialist in Russian affairs employed by the Foreign Office. ${ }^{5}$ Interviewed by the Home Office, Litvinov expressed surprise at his appointment but said he was ready to assume his duties as soon as he received confirmation of Trotsky's message. ${ }^{6}$ Meanwhile the Narkomindel (People's Commissariat of Foreign Affairs) announced Litvinov's appointment in Petrograd where the British ambassador, Sir George Buchanan, first read of it in the Soviet press on January 2. "Unless approached by Trotsky," he informed London, "I propose to take no notice of the appointment." The foreign commissar lost no time in calling attention to Litvinov's new status, and on January 4, Sir George had to advise London that some arrangement would have to be worked out to avoid a breach with the Bolsheviks. "If we refuse to receive him," he wrote, "Trotsky will retaliate by withdrawing our diplomatic immunities and by stopping all our cypher telegrams. As the Embassy could in such case be liable to search, we would have to destroy our secret archives and cyphers." In his opinion there was no choice but to recognize Litvinov as the agent of the Soviet government or withdraw the British embassy from Petrograd. Withdrawal was undesirable, for it would "leave a clear field to the Germans and would deprive all our vested interests in this country of the protection which we might give them." Thus he urged London to "come to some working arrangement" with Litvinov. ${ }^{8}$

The Foreign Office held much the same opinion. "It will be awkward if Mr. Litvinov appeals to us to expel Mr. Nabokoff and his staff from the

5. PRO F.O. $371 / 3298 / 1957$.

6. PRO F.O. $371 / 3298 / 2689$.

7. Ibid.

8. PRO F.O. $371 / 3298 / 3346$. 
Russian Embassy," wrote one high official, "but short of this we should be able to establish unofficial relations with him." Leeper's acquaintance with Litvinov and the decision which had just been made to send Bruce Lockhart to Petrograd to remain in unofficial contact with the Bolsheviks ${ }^{9}$ suggested a natural way to dispose of the problem. "I venture to suggest," wrote John Gregory, the head of the Russian Department in the Foreign Office, "that we should ask Mr. Leeper to act in relation to Mr. Litvinov much as Mr. Lockhart is to act in relation to Mr. Trotsky." Lord Hardinge found this an "admirable suggestion,"10 and when Litvinov wrote to the Foreign Office, officially informing it of his appointment as Russian plenipotentiary in London, the under secretary of state submitted this proposal to him as a solution to the problem of Bolshevik representation in Britain.11 Litvinov objected to the irregular and "unsatisfactory" nature of this proposal but agreed to it as a "temporary arrangement." This satisfied the Foreign Office where Lord Hardinge minuted: "he was bound to protest, but we need not enter into an argument."12

Litvinov's new status soon provided sufficient cause for argument. The Home Office, which was responsible for discouraging anti-war propaganda in Great Britain, had watched the succession of concessions to the Soviet government with growing apprehension and did not appreciate the unofficial recognition granted Litvinov by the Foreign Office. Foreign Secretary Lord Balfour had won the assent of his colleagues to these concessions only by arguing that it was vital to the British war effort to avoid a rupture with the Bolsheviks, but now that the Foreign Office had granted quasi-diplomatic status to Litvinov, Home Secretary Lord Cave had an equally pressing argument to present the Cabinet. Litvinov, he said, was a menace to the stability of British society and if allowed to exploit his new found status could do irreparable harm to civilian and military morale. He complained of the public statements made by Litvinov and told his colleagues that "in the past he had deported men for less objectionable propaganda."13 The Home Office refused to make any further concessions to the Bolshevik diplomat, placed him under close surveillance and, without informing the Foreign Office, clamped a ban on his communication with Petrograd. Litvinov soon complained that he was unable to contact his government, and the Foreign Office discovered that the Home Secretary had taken it upon himself to censor the

9. Great Britain, Public Record Office, London. Cabinet Papers, Record Group 23, Volume 4, Folio 278. See also Ullman, Intervention and the War, pp. 58-60.

10. PRO F.O. 371/3298/3346.

11. PRO F.O. $371 / 3298 / 4558$.

12. PRO F.O. $371 / 3298 / 10026$.

13. PRO F.O. 371/3312/11543. 
envoy's correspondence. Under pressure from the Foreign Office the Home Secretary agreed that Litvinov could communicate en clair with Petrograd but refused to sanction his use of cypher. ${ }^{14}$ Lord Cave's decision did not create an immediate crisis because Litvinov did not yet possess a set of cyphers to use in corresponding with Trotsky, but the incident boded ill for the future.

A cold war of sorts soon erupted in Whitehall with the Foreign and Home Offices both claiming primary responsibility for determining the fate of Litvinov. In general, the Foreign Office attempted to avoid giving the Soviet envoy cause for complaint, agreeing even to grant military exemptions to his assistants, ${ }^{15}$ but the Home Office continued to demand his expulsion. Calling attention to a leaflet prepared and distributed by Litvinov, Lord Cave described it as "a clear breach of the regulations" making it necessary for the Cabinet to "come to some decision as to the treatment to be meted out to him." Lord Robert Cecil, speaking for the Foreign Office, was again able to convince the rest of the Cabinet that the continued presence of the British embassy in Petrograd depended upon toleration of Litvinov's activities in London, but the seriousness with which the Government viewed the matter can be seen in their decision to seize the press which had printed Litvinov's leaflet and to launch a newspaper campaign to counter the propaganda disseminated by the Russian envoy. ${ }^{16}$

Litvinov did little to help the Foreign Office. Lord Hardinge repeatedly had Leeper warn the Russian envoy about meddling in British politics, but Litvinov asserted that he could not desist from criticizing Allied policy. Moreover, he emphatically denied that he had written any articles seeking to undermine the British war effort. Strictly speaking this was true, as was recognized by the Foreign Office, for the writings circulated by Litvinov were in fact translations of articles originally prepared by Trotsky and other Russian leaders. Understandably this did not satisfy Hardinge ${ }^{17}$ and made even less impression at the Home Office. Lord Cave was increasingly alarmed by the activities of Litvinov, and, in February, sent a report to the Foreign Office containing a number of new allegations against the Soviet envoy. The police listed attempts made by Litvinov "to get British and American soldiers of Jewish descent to visit his office to induce them to engage in propaganda in their regiments," to distribute propaganda among workmen, and to engineer "a mutiny on board two Russian patrol vessels lying in the Mersey."18

14. PRO F.O. $371 / 3298 / 9300 ; 371 / 3298 / 10017$.

15. PRO F.O. $371 / 3298 / 13444$.

16. PRO F.O. $371 / 3312 / 16563$.

17. PRO F.O. 371/3298/28849; 371/3299/31794.

18. PRO F.O. 371/3299/33471. 
A few days later Sir Basil Thomson of Scotland Yard added the frightening but unsubstantiated charge that Litvinov was also attempting "to organize a Red Guard among 23,000 Russian Jews in the East End" of London, linking this incongruously with the triumphant declaration that he had also discovered that Litvinov was "guilty both of registering and marrying under a false name." "If Litvinov had been an ordinary Russian," wrote Sir Basil, "we should certainly have taken proceedings against him ere now." The latter charge led Lord Balfour to comment acidly: "If he ought to have been arrested for marrying under a false name, why did the police not do it before he became a diplomatic person?"'19 The Foreign Secretary, who was fully aware of the unsavory activities of British diplomats in Russia at this time, did not find any of these charges particularly shocking, but his colleagues thought otherwise. By mid-February when the great crisis in Soviet-German negotiations burst upon the chancelleries of Europe the British government was barely restraining itself from expelling the Soviet representative in London. ${ }^{20}$

Nor were new requests by the Soviet government for additional diplomatic representation in the British Empire received joyously. The nomination of John MacLean as Soviet consul in the volatile city of Glasgow and that of a certain Skevensyreff as consul-general in India were received with horrified incredulity. MacLean, it turned out, was a "convict on license" under close police surveillance. He had only recently been released from prison where he had been sent in 1916 for making seditious speeches along the Clyde. Nothing was known of Skevensyreff, but the India Office flatly refused to let him go to India in any capacity. Lord Hardinge instructed the British embassy in Russia to inform Trotsky "that although we are anxious, as he is aware, to meet his wishes as far as we are able within reason, we can not entertain the proposal." A similar message was sent concerning MacLean. ${ }^{21}$

In this poisonous atmosphere the Soviet government chose to launch its most ambitious diplomatic cum revolutionary venture since the start of peace negotiations with Germany. The scheme, which had been maturing in Bolshevik minds since late December, centered on securing a more public forum for revolutionary propaganda than that offered by the German citadel at Brest-Litovsk. The first attempt to break out of the German straight-jacket had failed when the Central Powers refused to consider Trotsky's suggestion that negotiations be moved to Stockholm, but in mid-January, toward the

19. PRO F.O. $371 / 3299 / 37234$.

20. Ibid. Lord Robert Cecil, the Parliamentary under secretary of state for foreign affairs, minuted on Thomson's report: "Personally I feel convinced we shall have to expel Litvinov, and I see very little objection to that being done."

21. PRO F.O. 371/3298/15369; 371/3298/20491. 
end of the second session of the peace conference, the Russian delegation hit upon another means of expanding their audience. If the Germans would not agree to move the conference, the Bolsheviks would send part of their delegation to Stockholm where it would establish a center from which the Soviet peace program could be explained to the world. Lev Borisovich Kamenev was chosen to lead this mission. Kamenev, in fact, left Brest-Litovsk prior to the end of the second session and returned to Petrograd to prepare for his trip to Sweden. Before he could complete his preparations word arrived of the riots and disturbances which shook Central Europe in late January 1918. ${ }^{22}$ Soviet leaders, in response to this news, expanded the scope of his mission, and when it was first announced on January 29, the Soviet press reported that Kamenev was being sent to London and Paris as a special delegate from the Sovnarkom (Council of People's Commissars) "to acquaint the governments and peoples of the Allied countries of the course of the peace negotiations." Ivan Zalkind, who had served until then as Trotsky's deputy at the Narkomindel, was being sent to Switzerland on the same mission. ${ }^{23}$

Jacques Sadoul, who served as an unofficial French liaison officer with the Bolsheviks, wrote on January 30, that "the decision in principle to send a delegation was made a long time ago," 24 but the few Soviet sources available on the subject leave no doubt that the January strikes in Central Europe actually triggered the decision to send Kamenev and Zalkind to the West. "I was present in the Narkomindel one January morning at 3 o'clock," wrote the American journalist John Reed, "when news of the great German strikes arrived. Immediately all was hilarious excitement. Commissars were to be sent all over Europe immediately." 25 Zalkind adds further: "In the middle of January 1918 (o.s.), the first reports were received of large scale unrest among workers and sailors in the countries of the Central Powers. . . It was decided on our part to send Comrade Kamenev to France and me to Switzerland in order to confront the Entente countries with the reality of the socialist revolution in Russia." 26 In a telegram to Trotsky, who was then at Brest-Litovsk, Georgii Chicherin, who had just been appointed acting foreign commissar, provided much the same information, indicating as well that the Soviet government had originally intended to send Peter Petrov with Kamenev and Zalkind, but had changed its mind after receiving a protest

22. D. G. Fokke, "Na stsene i za kulisami Brestskoi tragikomedii," Arkhiv" russkoi revoliutsii, 20, p. 161. Also see John W. Wheeler-Bennett, Brest-Litovsk: The Forgotten Peace (London, 1938), pp. 196-197.

23. PRO F.O. 371/3315/19692.

24. Jacques Sadoul, Notes sur la Révolution Bolchevique (Paris, 1920), p. 215.

25. Cited in Kennan, Russia Leaves the War, p. 403.

26. Ivan A. Zalkind, "N.K.I.D. v semnadtsatom godu," Mezhdunarodnaia zhizn', no. 10 (1927), pp. 15-25. 
from Lockhart. The British agent had made it clear that Petrov, who had just been expelled from England, would not be allowed to land in Great Britain. ${ }^{27}$ Kamenev, therefore, was assigned the dual task of reinforcing Litvinov and establishing a Soviet embassy in Paris.

If the origin of the mission is clear, the exact purpose is not. Zalkind gives no hint of how the mission was "to confront the Entente countries with the reality of the socialist revolution in Russia." Chicherin is similarly vague. "We discussed this question," he wrote, "and decided that our strength was in attack and that whatever would happen would be the worse for Lloyd George and Company, and the Revolution would be the gainer."28 Soviet sources cast no further light on the subject, presumably because Kamenev was later purged by Stalin and has not yet been posthumously rehabilitated. His role in the revolution remains under a cloud, and Soviet historians are not eager to publish information about his mission. A telegram from General Niessel, chief of the French military mission in Russia, to the Ministry of War in Paris, however, probably contains the substance of Kamenev's instructions. This message, sent on January 31, indicates that Kamenev had been instructed "to evaluate the state of mind of the socialist parties in the different belligerent countries, to gather information on public opinion in regard to the Bolsheviks, to see if the European proletariat is ready to support the Russian proletariat in provoking the international social revolution and to calculate the moment when this international movement will become possible."29 A later telegram from Niessel reported that Kamenev had also been instructed to speak with the British and French governments in order to explain Bolshevik foreign policy and the problems encountered in the negotiations at Brest-Litovsk. ${ }^{30}$ Niessel identified Sadoul as the source of his information, and as the French captain was particularly close to the Soviet leaders it is reasonable to assume that, in so far as it went, this information was accurate. It fits within the vague guidelines mentioned by Chicherin and Zalkind while corresponding with the needs and aspirations of the Bolsheviks at this time. The picture of Kamenev's mission which emerges from this evidence is that of a "fishing expedition" designed to gather information and present the Bolshevik point of view to Western Europe, particularly to the socialist parties in England and France.

27. Edgar Sisson, One Hundred Red Days: A Personal Chronicle of the Bolshevik Revolution (New Haven, 1931), p. 303.

28. Ibid., p. 304.

29. France, Archives du Ministère des Affaires Étrangeres, Quai d'Orsay, Paris. Record Group: La Guerre de 1914-1918. Russie, Action des Allies; Volume 32; Folios 62-63. Hereafter cited as MAE, followed by collection title, volume and folio numbers.

30. MAE, Guerre, Russie, Action des Allies, 32/66. 
Why should Kamenev have been chosen for this venture? There is no document which provides a direct answer to this question, but circumstantial evidence suggests that he was chosen because he stood a better chance than any other Soviet leader of successfully completing the mission. Kamenev was well known in Western Europe and, because of his earlier opposition to the more high-handed policies of Lenin's government, ${ }^{31}$ he had acquired a reputation for moderation which other Bolshevik leaders did not possess. In Sadoul's words he was "cultivated and supple, capable of understanding everything reasonable while incapable of descending into a mystical obstinacy." ${ }^{32} \mathrm{He}$ was also known as an ardent internationalist and since his return from BrestLitovsk, where he had been a member of the Soviet delegation during the first two sessions of the Peace Conference, "he had not ceased to alert the Bolsheviks to the hypocrisy and covetousness of the Germans." 33 Thus, while his reputation as a moderate would secure him a hearing among leading Western socialists, his opposition to peace with Germany was likely to make him persona grata with the Allied governments. Moreover, as a moderate he was unlikely to excite the fear which a man such as Peter Petrov was bound to arouse in Western Europe. There is, however, no evidence to substantiate Wheeler-Bennett's contention that Kamenev carried "a message urging the Powers to give assistance to the Bolsheviks in resisting the Germans and in refusing to sign the peace." 34

Far from sending Kamenev with a secret message asking Allied assistance, a good case can be made for the hypothesis that Lenin seized the opportunity of the proposed mission to remove an influential opponent from the locus of revolutionary power. The very reasons which made Kamenev acceptable in Western Europe made his presence in Petrograd intolerable to Lenin. By late January, Lenin had already decided it was necessary to junk Soviet Russia's original foreign policy and formulate a new one based on the realities of power in Eastern Europe. Unwilling to stake the fate of the Russian Revolution on the possibility of inciting one in Germany he had already told the Bolshevik Central Committee: "Germany is only pregnant with revolution, in our country we already have a very healthy baby-the

31. See Leonard Schapiro, The Origin of the Communist Autocracy (New York, 1965), pp. 52-88.

32. Sadoul, Notes, p. 215.

33. Ibid.

34. Wheeler-Bennett, Brest-Litovsk, p. 284. Wheeler-Bennett seems to have been misled by former members of the British Foreign Office whom he consulted when preparing his work. This erroneous information not only caused him to make the inaccurate statement noted above, but also to place the origin of the Kamenev mission in the wrong context, dating its inception from the crisis of late February when the Bolsheviks seemed ready to accept Allied aid against Germany instead of late January when it actually began. 
Socialist Republic-which we will murder by resuming the war."35 Instead, he wanted to purchase peace from Germany at the price demanded at BrestLitovsk so that he could turn his attention to the consolidation of power in Russia and the total destruction of the Russian bourgeoisie as a social class. ${ }^{86}$

Kamenev, on the other hand, was a sworn enemy of both peace with Germany and the ruthless methods Lenin wished to use in destroying the former ruling classes. Worse yet, from Lenin's point of view, Kamenev was not just an occasional opponent of his policies but a persistent critic who had opposed every policy which he had put forth in the past year. His opposition had reached a peak in November, when, at the time of the insurrection, he had not hesitated to expose the Bolshevik plans for a coup d'état in an effort to prevent Lenin from seizing power. Kamenev was, in fact, as the French police described him in a report to the Quai d'Orsay, "very intelligent and ambitious, jealous even of Lenin and desirous of playing an important role." This "important role" had heretofore been denied him, but the great debate within the Bolshevik Party over the future course of Soviet foreign policy afforded him new scope for his ambitions. Lenin had to reckon on Kamenev repeating his previous performance, not merely opposing peace within the Bolshevik Party but carrying his opposition into the ranks of all those groups which wanted to launch a revolutionary war against German imperialism. Kamenev was particularly dangerous because his conciliatory approach to the Right Social Revolutionaries, and even to the more liberal bourgeois groups within Russia, made him an outstanding candidate to lead the type of political movement Lenin dreaded most, a government of union sacrée dedicated to driving the German invader from Russian soil and submerging class conflict in a great efflorescence of Russian nationalism. This must remain conjecture, but there is more than ample reason for believing that Lenin wanted Kamenev as far from Russia as possible when the great crisis over foreign policy finally came to a head.

The crisis in Russian foreign policy, in fact, was to determine the entire course of the Kamenev mission. Given birth by the riots in Central Europe which rekindled hopes of the imminent spread of the revolution to other parts of the continent, the mission received permission to proceed to Western Europe only because the Allied governments believed there was a good chance that the Soviets would reject the peace terms offered them at Brest-Litovsk.

35. Institut Lenin pri TsK VKP (b), Protokoly Tsentral'nogo komiteta RSDRP (b): Avgust 1917 g.-fevral' 1918 g. (Moscow, 1929), pp. 199-207.

36. Ibid. Also see V. I. Lenin, Polnoe sobranie sochinenii, 5 th ed., 55 vols. (Moscow, 1958), 35:191-194, 243-251.

37. MAE, Guerre, Russie, Action des Allies, 32/64. 
The failure of anti-Bolshevik movements, especially the Ukrainian Rada, to resist German expansion in Eastern Europe and the expectation that the Soviet government was prepared to stand up to Berlin led Allied leaders to alter their policies toward Russia. For a brief moment, the Entente was prepared to submerge its hostility to the Soviet government and work toward a limited form of cooperation wth the Bolsheviks, ${ }^{38}$ a change that was decisive in permitting the Kamenev mission to proceed as far as it did.

Ironically, France took the lead in approving Kamenev's journey to Western Europe-heretofore Paris had steadfastly rejected the idea of receiving a Bolshevik envoy. Early in January, when Litvinov's appointment had forced the British government to face this problem, the French government declared that it "would not be able to recognize a mission emanating from a non-recognized government which does not adhere to the previous agreement that diplomatic usages demand." 39 By early February, under the pressure of changed circumstances in Eastern Europe and Germany's impending offensive on the Western Front, the French had changed their minds. Thus, when the British government solicited the French view on the Kamenev mission the Quai d'Orsay replied:

The Government of the Republic has taken necessary measures to have Messieurs Kamenev and Zalkind watched very closely on their arrival in France. On it being shown that they are engaged in any action contrary to the general interests of the Allied Governments and to the conduct of the war of a nature to cause disorder or discouragement in France energetic measures will be taken to put an immediate stop to such conduct.

The original draft had contained a final clause saying "and in that instance the two individuals involved will be deported," 40 but it was deleted before the note was sent, presumably because the Quai d'Orsay did not wish to alarm London by speaking of deportation before Kamenev and Zalkind had even arrived. To be sure the two men would be expelled from France if they sought to disseminate revolutionary propaganda, but there was no need to spell this out for the British who might seize upon it as an excuse for not allowing the Bolshevik envoys to pass through Great Britain. This was a most significant change in policy. It corresponded with the advice Paris was then receiving from its missions in Russia, but, as the Quai d'Orsay apparently suspected, it was not particularly appreciated in London. A startling reversal, in fact, had overtaken British and French attitudes concerning fur-

38. MAE, Guerre, Russie, 29/5; PRO F.O. 371/3299/32015.

39. MAE, Guerre, Russie, Action des Allies, 28/43.

40. MAE, Guerre, Russie, Action des Allies, 32/74-75. 
ther concessions to the Bolsheviks. London, which originally sponsored the policy of unofficial recognition of the Soviet government, was now reluctant to receive Kamenev and Zalkind, while Paris, which had formerly been dragged along unwillingly in the wake of British policy, seized the initiative. The Foreign Office, doubting the wisdom of its original policy and alarmed at the prospect of more Soviet representatives travelling through Western Europe, had hoped that the French would veto the Kamenev mission. If they had done so the British would then have had a convenient excuse for prohibiting the Bolsheviks from entering Great Britain while shifting responsibility for this decision onto French shoulders. The Quai d'Orsay, having abandoned its earlier intransigence, no longer left the British an easy way out of the situation. "In these circumstances," wrote John Gregory, "we have no alternative but to do likewise." 41 Kamenev and Zalkind, because of this surprising turn of events, were given permission to enter Britain and France.

No sooner had this decision been made than pressure began to mount to reverse it. In France, the arrival of Edward Holzmann, the first diplomatic courier dispatched by the Soviet government to Western Europe, gave the French government reason to reconsider its decision. Holzmann made no secret of his instructions "to hold conferences in London and Paris for the purpose of explaining Bolshevik policies and peace plans to the trade unions" and during his stay in Paris met with various French socialists and Russian émigrés. ${ }^{42}$ Irked by the close surveillance to which he had been subjected he complained to the Quai d'Orsay of his "surprise that in France, cradle of the revolution, a courier of a revolutionary government" would be treated in this manner. ${ }^{43}$ If this was how a simple courier acted, the French could well ask how a Bolshevik plenipotentiary would behave? News from Stockholm soon provided an answer, for during the second week in February Kamenev and his party reached the Swedish capital on their way to Western Europe. They had been delayed by the civil war in Finland, but once in Stockholm they lost no time in setting about the tasks assigned them. Kamenev met with numerous revolutionary groups, while Zalkind called on the Russian minister to demand that he turn over the embassy to the Soviet government. French military intelligence in Stockholm kept close tabs on them, reporting their every move to Paris. ${ }^{44}$ Disturbing as these activities may have been, they were nothing when compared to an interview that Kamenev granted to the Swedish journal Politiken on February 13. In the interview, given shortly after Trotsky's declaration of "no war, no peace"

41. PRO F.O. 371/3315/19692.

42. MAE, Guerre, Russie, Action des Allies, 32/76-78, 86.

43. MAE, Guerre, Russie, Action des Allies, 32/82-83.

44. MAE, Guerre, Russie, Action des Allies, 32/99, 116. 
at Brest-Litovsk, the Soviet envoy indiscreetly gave his views on a wide range of topics including his intended activities in France. An account of the interview was immediately sent to Paris, the French ambassador reporting that Kamenev "does not hide that he and his friends are going to England and France to provoke the revolution. He adds that the German troops freed by the peace with Russia will produce a favourable pressure on the Western Front for peace." "After these cynical declarations," asked the incredulous ambassador, "will he be authorized to stay in France?" Weighing the circumstances, with renewed Soviet-German hostilities still a possibility, he advised that "the best course would be to let him come, but then to see that he is isolated and kept quiet." Paris concurred, ${ }^{45}$ but understandably grew increasingly uneasy over the impending arrival of the Bolshevik envoys in France. ${ }^{46}$

Across the Channel, the British government was also suffering a bad case of the jitters. On February 14, the Home Office, having sifted the intelligence reports from Stockholm, informed Balfour that "it appears . . . very undesirable that Kameneff and his companion should be allowed to proceed to this country." If the Foreign Office insisted on allowing the Bolsheviks to enter Britain, however, Lord Cave declared that he intended to see to it "that they will be required to pass straight through this country and they will not be allowed to return from France unless and until arrangements have first been completed for them to travel straight through to Russia again." This memorandum arrived in the Foreign Office at precisely the time British hopes for Bolshevik resistance to Germany were at their highest and Balfour, consequently, had no intention of allowing the Home Office to spirit Kamenev through Britain without the Foreign Office first having an opportunity to speak with him. The Foreign Office, therefore, informed Lord Cave that "Kameneff has been appointed representative of the Bolshevist Government on a special mission to this country among others. Mr. Balfour accordingly contemplated Kameneff remaining in England for some little time." The Home Office was warned to avoid any action which might unnecessarily give offense to the Bolshevik plenipotentiary. Zalkind, on the other hand, being accredited to Switzerland and of no interest to the Foreign Office, was consigned to the tender mercies of the police. He could, said the Foreign Office, be passed through the country as rapidly as the Home Office desired. ${ }^{47}$ In short, as long as there was hope that the Bolsheviks would continue to pin the Germans to the Eastern Front the Foreign Secretary considered Kamenev persona grata, and not even a report arriving on February 16 that British

45. MAE, Guerre, Russie, Action des Allies, 32/124.

46. MAE, Guerre, Russie, Action des Allies, 32/119.

47. PRO F.O. $371 / 3315 / 29125$. 
intelligence in Norway believed that the Russian envoys were "carrying with them the whole or part of the two million rubles recently voted at Petrograd for propaganda in Allied countries" made any difference to him. ${ }^{48}$

All this suddenly changed with the Bolshevik decision to sue for peace. Just as quickly as Kamenev had become a source of interest to the Allied governments he now became an unwanted embarrassment and a troublemaker to be disposed of as quickly as possible. Pending final clarification of Bolshevik intentions, the Foreign Office, on February 23, decided to hold Kamenev at Bergen, but the telegram carrying these instructions arrived too late to stop him from sailing for Aberdeen. ${ }^{48}$ This led to a hasty conference of British officials who sought to determine how Kamenev should be treated when he came ashore in Scotland. The Home Office, having read the latest dispatches from Bergen, now feared that he was bringing with him "all the apparatus for revolutionary propaganda" and wished to seize his baggage when he arrived. This raised a rather delicate question of international law, but it was easily answered by the mandarins of the Foreign Office. Lord Hardinge pointed out that the question of the seizure of Bolshevik baggage depended on which member of Kamenev's party presented it for inspection.

If the baggage bears the seals of the Russian Government and is brought by courier [he wrote] it may be seized but only opened in the presence of M. Litvinoff or his agents. If on the other hand it comes as M. Kameneff's property or baggage it can be opened at once in the Customs Office-he enjoys no diplomatic immunity. In each case all propaganda materials should be held up. Salkind [sic] is in the same category as Kameneff. ${ }^{50}$

Having hit upon this legal subterfuge and having conveniently forgotten that a few days before Lord Balfour had solemnly declared that Kamenev "had been appointed representative of the Bolshevist Government on a special mission to this country among others" the Foreign Office provided the police with the authority they needed to place the Soviet envoys under virtual arrest when they stepped ashore.

The improvised plan worked perfectly. Not suspecting the changed attitude in London and unversed in the subtleties of international law, Kamenev and Zalkind made the mistake of claiming most of the mission's baggage as

48. PRO F.O. $371 / 3315 / 35184$.

49. PRO F.O. 371/3315/34847. The two Bolsheviks, in fact, landed at Aberdeen on February 23.

50. PRO F.O. 371/3315/36741. 
their own and had to stand by helplessly as it was seized and carried off by the police. They were also forced to submit to a search of their persons, Kamenev being relieved of a check drawn on a London bank for five thousand pounds sterling while Zalkind had to surrender ten thousand francs which he had been carrying. Although they were promised that their baggage would be returned to them unopened when they left the country Scotland Yard decided to inspect that of Zalkind, preparing a carefully itemized inventory of its contents. Included were thirty blueprints of Russian warships "together with a list stating that a certain appliance supplied by the British Admiralty had been affixed to them," a report concerning the movement of British submarines in the Baltic, two automatic pistols, one rifle and a large quantity of miscellaneous propaganda material. "The only part of all this luggage that could legitimately be allowed to come into this country," wrote the inspecting officer, "is certain worn and very dirty clothing and some private notes and memorandum." 51 There is no indication that Kamenev's baggage was searched; that of the diplomatic courier, who arrived with the envoys and whose pouches should have been turned over to Litvinov, was "mysteriously" misplaced, its fate not being determined until several months later when after "careful checking" Scotland Yard reported that, because of "some misunderstanding at Aberdeen," the courier pouches had been put aboard the ship returning him to Bergen. ${ }^{52}$ Through "muddle" and mendacity, therefore, the British police had successfully disposed of the "apparatus for revolutionary propaganda."

Having relieved the Bolsheviks of their money and baggage, the British authorities still had to cope with the unwanted presence of Kamenev and Zalkind. Kamenev, livid with anger, threatened reprisals against British personnel in Petrograd, and Litvinov protested immediately to the Foreign Office promising the most serious consequences if they did not promptly return the envoys' baggage and offer suitable apologies. To avoid possible Bolshevik reprisals, steps were taken to prevent Kamenev from communicating with Petrograd, while Litvinov was fobbed off with a series of lame

51. PRO F.O. 371/3315/41362. This inventory raises some rather interesting questions about the purpose of Zalkind's mission to Switzerland. If he was engaged in the same type of enterprise as Kamenev, why should he be carrying blueprints of Russian warships and a report concerning the movement of British submarines in the Baltic? As Zalkind intended to use Switzerland as a base for revolutionary propaganda in Germany he may have been intending to use these items as some type of "bait" to tempt the German authorities, but it is still difficult to account for their presence in his baggage. British Foreign Office sources unfortunately do not throw any light on the subject, simply stating that "in the opinion of the Admiralty Division Representative this information would be very valuable to the enemy, and it is considered dangerous."

52. PRO F.O. 371/3315/46733. 
excuses including the palpable untruth that the British government had been unaware that Kamenev and Zalkind enjoyed the status of ministers plenipotentiary. Arrangements would be made, Litvinov was promised, to provide them with transportation to Paris ${ }^{53}$ Having established close surveillance over Kamenev and Zalkind, the British government sat back to observe the attitude which Paris would take concerning their arrival in France. "It will be interesting to see how the French treat these people," wrote John Gregory, "probably not too leniently." 54

Paris, for its part, had been watching how the British handled the situation. Kept abreast of developments in London by their ambassador ${ }^{55}$ the French government met early on the evening of February 26 to reassess its policy on the Bolshevik envoys. Before them they had the report from London, full documentation on the activities of Holzmann in Switzerland, ${ }^{56}$ and telegrams from Petrograd indicating that a new wave of Bolshevik agents was about to embark for Western Europe. ${ }^{57}$ Most important, they were aware that Lenin's government had already accepted the German terms of February 21 and would sign the Peace of Brest-Litovsk. The result was a series of decisions telegraphed to French diplomatic outposts that evening. The French minister in Stockholm was informed that as those Bolsheviks sent abroad "have more and more revealed themselves as propagators of the most dangerous ideas, as creators of disorder and dedicated to upsetting established governments, the French Government has resolved to forbid henceforth their access to French territory." Consequently, he was to issue no further visas for representatives of the Soviet government. ${ }^{58}$ In the same vein, the French ambassador in Berne was ordered to refuse a visa for Holzmann should the Soviet courier seek to return to France. ${ }^{59}$ Finally, the French ambassador in London was instructed to inform Kamenev and Zalkind that they would not be allowed to enter France. ${ }^{60}$ With these telegrams the French government washed its hands of the problem. The next morning the startled officials at the Quai d'Orsay discovered to their horror that they had done no such thing, for the instructions sent their ambassador in London had crossed an incoming telegram from him informing them that Kamenev and Zalkind were ready to leave for Le Havre. ${ }^{61}$ At the same time as the French foreign minister opened

53. Ibid. Also see PRO F.O. 371/3299/36404.

54. PRO F.O. $371 / 3315 / 35184$.

55. MAE, Guerre, Russie, Action des Allies, 32/157.

56. MAE, Guerre, Russie, Action des Allies, 32/125, 129, 130-135, 142, 155.

57. MAE, Guerre, Russie, Action des Allies, 32/100-101.

58. MAE, Guerre, Russie, Action des Allies, 32/161.

59. MAE, Guerre, Russie, Action des Allies, 32/159.

60. MAE, Guerre, Russie, Action des Allies, 32/160.

61. MAE, Guerre, Russie, Action des Allies, 32/158. 
this telegram, he received a note from the British ambassador informing him that as Kamenev had officially described himself as "representative of the Russian Republic to France we are, therefore, sending him on to France, as well as Salkind [sic], as soon as possible." "A fine gift!" Pichon scribbled on the note as he reached for the telephone to intercept the duo before they reached France. The prefect of police at Le Havre, the French consul at Southampton and the ambassador in London all received preemptory orders instructing them to prevent Kamenev and Zalkind from sailing for France, or, if they had already left, to insure their immediate return to England. ${ }^{62}$ The telephone calls and telegrams had their desired effect. The Bolshevik envoys, who had been due to leave for Paris by the four o'clock boat train, were intercepted at Litvinov's office where they were told they would not be allowed to enter France. The continental aspect of the Kamenev mission was thus ended before it had even begun.

The French decision left both the Bolshevik envoys and the British government in a rather embarrassing position. Zalkind, refused passage through France, could not proceed to Switzerland, and the British were certainly not going to allow him to stay in England. Kamenev could probably have insisted on remaining, but it was perfectly clear that he would accomplish nothing in doing so. If he had any doubts they were surely resolved when one of the Soviet envoys (the Home Office report does not say which) attempted to visit the Communist Club in the East End of London. No sooner had he arrived than the police raided the building, cleared the premises and took all its occupants away for questioning. ${ }^{63}$ Nor was Kamenev allowed to speak with anyone of importance in the British government. He was given the same treatment as Litvinov and permitted to talk only with junior officials and intelligence officers. These men, Lewis Namier among them, found Kamenev fascinating but learned nothing new from him. ${ }^{84}$ Thus, when Lord Cave pressed his demand for the prompt expulsion of the two Bolsheviks the Foreign Office did not object. The Home Office also wanted to expel Litvinov, but the Foreign Office would not hear of it, insisting that he be allowed to remain so as not to cause the Bolsheviks to expel Lockhart from Russia. Finally, on February 28, still protesting his treatment, Kamenev indicated that he was ready to comply with the wishes of the police, and early in March he took ship for Norway. ${ }^{65}$ This, however, did not end his adventures, for in mid-month, on his way back to Russia, he was taken prisoner by the

62. MAE, Guerre, Russie, Action des Allies, 32/158, 165, 167.

63. PRO F.O. $371 / 3315 / 35127$.

64. PRO F.O. $371 / 3315 / 42956$.

65. PRO F.O. $371 / 3315 / 38742$. 
White Finns. He then became the subject of a protracted dispute carried on at long distance between Helsingfors and Moscow, the Finns demanding the extradition of several Finnish Communists in exchange for the Soviet envoy. Only after Germany agreed to mediate was the issue settled, and in mid-July, over four months after leaving London, Kamenev was allowed to return to Soviet Russia. ${ }^{8 \theta}$

Such was the dismal end to an ill-conceived mission dispatched at precisely the wrong moment to achieve success. With the exception of Lenin, who profited immensely from Kamenev's absence, no one benefited from the journey. Kamenev and Zalkind had been sent on a wild revolution chase ending in disappointment and humiliation. Except in a negative sense, they failed to accomplish any of the tasks which had been set them before leaving Petrograd. They had wanted to take the pulse and read the temperature of West European revolutionary movements, hopefully administering an invigorating shot of adrenalin to the lethargic proletariat. In no way did they succeed. Their presence in England had little effect on public opinion, and the ease with which the British and French governments ran them out of Western Europe could only indicate that the level of proletarian internationalism in that part of the continent was exceptionally low. In the end their mission only served to heighten tension between the Allied and Soviet governments at a time when, independent of this irritation, the governments concerned were already drifting perilously close to open hostilities.

Litvinov remained in London, but with the shift in Soviet foreign policy marked by the decision to sign the Treaty of Brest-Litovsk his role quickly changed. Originally intended as a revolutionary plenipotentiary, a missionary of proletarian internationalism among the heathens and schismatics of darkest Britain, he increasingly became a token envoy ignored in both London and Moscow. Tolerated in Britain only because of Lockhart's continued activities in Russia, Litvinov was condemned to spend the next six months isolated from both British society and the government he served. The police efficiently saw to the first aspect of this isolation while the Soviet government abandoned him to the second. Litvinov himself later provided the measure of Moscow's lack of interest in him at this time. Telling his friend I. M. Maiskii how, in March 1918, he finally received his first diplomatic "mail" from the Soviet government, he said:

The courier arrived with a large bag covered all over with diplomatic labels, and it was in a state of great excitement that I carried it from the

66. G. V. Chicherin, Two Years of Soviet Foreign Policy (New York, 1920), pp. 19-20. Zalkind, who travelled with Kamenev only as far as Sweden, eventually succeeded in reaching Switzerland by way of Germany. 
station to my room. Even greater was my excitement as I started to open this precious receptacle which I expected to contain all the instructions and orders I needed. Imagine my dismay on finding a pile of the latest Moscow papers but not a single directive! ${ }^{67}$

In far distant Russia, Lenin had assumed full command of Soviet foreign relations and was structuring a radically different policy from the ultrarevolutionary course which had been followed by Trotsky. In March 1918, survival rather than revolution became the watchword of the Soviet regime, and the demonstrative gestures with which Trotsky had introduced Soviet diplomacy to an astonished world came to an end. As a part of this change in policy Trotsky's effort to obtain Soviet representation abroad was also ended. Litvinov and Kamenev, therefore, became redundant and were virtually abandoned by the Soviet government. In the months ahead Soviet diplomacy would concentrate on the realities of power rather than the unsupported projection of poorly prepared political missions into the hostile world of Western Europe. When Bolshevik plenipotentiaries once more ventured beyond Russia they would go armed with much more than revolutionary rhetoric and would be backed by the full authority of the Soviet state.

67. Ivan Maisky, Journey into the Past (London, 1962), p. 63. 